УДК 378.091.212:005.336.2

DOI: 10.37026/2520-6427-2020-101-1-129-132
Олена НИкОН,

доиент кафедри гри на музичних інструментах

Рівненського державного гуманітарного університету

\title{
ФОРМУВАННЯ ПРОФЕСІЙНИХ КОМПЕТЕНЦІЙ СТУДЕНТІВ-МАГІСТРАНТІВ МУЗИЧНОГО МИСТЕЦТВА ЗАСОБАМИ ІНТЕРАКТИВНОГО НАВЧАННЯ
}

\begin{abstract}
У статті проаналізовано питання формування професійних компетениій студентів-магістрантів музичного мистецтва як майбутніх викладачів закладів вищяої освіти. Наведено приклади використання інтерактивних методів навчання під час проведення практичних занять із дисчииліни «Інтерактивні технології в галузі музичного мистецтва». Застосування в межах даного курсу дискусійних методів, рольових імітаційних ігор та тренінгів розглянуто у двох аспектах: вивчення навчального матеріалу та вдосконалення професійних якостей здобувача освіти.
\end{abstract}

Ключові слова: підготовка магістрів, інтерактивні технології навчання, дискусійні методи, методи проведення практичних занять, тренінг.

В статье проанализирован вопрос формирования профессиональных компетенций студентов-магистрантов музыкального искусства как будущих преподавателей учреждений выстего образования. Приведены примеры использования интерактивных методов обучения в проведении практических занятий по дисииплине «Интерактивные технологии в системе музыкального искусства». Применение в рамках данного курса дискуссионных методов, ролевых имитационных игр и тренингов рассмотрено в двух аспектах: изучение учебного материала и совершенствования профессиональных качеств соискателя образования.

Ключевые слова: подготовка магистров, интерактивные технологии изучения, дискуссионные методы, методы проведения практических занятий, тренинги.

In the article the question of forming of professional competences of master's degrees of musical art actualizes as future professors of higher education. The examples of the using the interactive methods of studies are in practical classes of "Interactive Technologies in Industry of Musical Art». This course includes using debatable methods, role plays, trainings examined in two aspects is a study of educational material and improving learning professional material. Forming professional skills of master's degrees include the perfection of professional qualities of master's degree in the resulted examples of practical workshops which include snow ball, jigsaw, conference, trainings methods. It has to be admitted that the use of interactive methods in the study of professional disciplines is instrumental and effectively helps to soak up the material. Practical workshops which are conducted on the basis of interactive material cause to visible results. Furthermore, forming communicative skills, capacity of future teacher for active co-operation with participants in educational process in a lecture hall and engaging using modern methods of teaching in disciplines in the future professional activity. The problems in this work need subsequent study. It is so necessary to justify and expressly define the criteria of preferential evaluation of students' knowledge according to the method of interactive studies, which must stimulate their educational activity and to engage students. Thus, organization of educational process on principles of interactive studies forms personality of teacher, capable professionally to operate and effectively react on modern problems.

Key words: preparation of master's degrees, interactive technologies of studies, debatable methods, methods of caring on practical classes, training.

Постановка проблеми. В умовах реформування вищої освіти важливим завданням $є$ впровадження в освітній процес нових методів викладання, спрямованих на покращення якості освіти. Неабияка увага при цьому приділяється розробці програм підготовки фахівців за новітніми технологіями, в основі яких формування загальних і професійних компетенцій, визначених освітньо-професійною програмою. Сучасні форми організації освітнього процесу передбачають нові методи роботи зі студентами, наприклад, інтерактивні технології, що грунтуються на взаємодії «студент - студент», «викладач - студент» та характеризуються комфортними умовами навчання. Переконані, що впровадження у навчальний процес дискусій, тренінгів, рольових дидактичних ігор тощо надзвичайно позитивно відобразиться на підготовці майбутніх викладачів спеціальності «Музичне мистецтво». 
Аналіз наукових досліджень і публікацій. Проблеми впровадження в освітній процес підготовки фахівців музичного мистецтва нових методів навчання розглядаються значною кількістю науковців та викладачів закладів вищої освіти (далі - 3ВО). Так, Г. Падалка визначає методологічні орієнтири (гуманістична спрямованість, національна основа мистецької освіти, створення адаптивних технологій, зумовлених принципами особистісно орієнтованого підходу до мистецького навчання тощо), якими слід керуватися при виборі методів музичного навчання [3, с. 63].

Стверджуючи, що магістратура - це освітній фініш, який $є$ стартом «неперервної освіти впродовж життя, професійного зростання, творчої самореалізації», Л. Лісовий аналізує проблеми підготовки магістрів музичного мистецтва, можливості їх професійного розвитку в контексті сучасних вимог [3, с. 6-7].

У працях Г. П'яткової, Е. Пєхоти, О. Глотова розглядаються інтерактивні технології та методика їх застосування у ЗВО. Зокрема, Г. П'яткова доводить, що інтерактивна методика навчання допоможе розвинути в студентів здатність до активної взаємодії в аудиторії, правильного проведення дискусії, аналізу, підніме рівень комунікативних здібностей випускників, а як наслідок - якість засвоєння матеріалу [6, с. 6-7]. Об'єктом досліджень Г. Козлової і Т. Клубнікової є компетентнісний підхід до навчання студентів. Автори стверджують, що означений підхід є підгрунтям для розробки освітніх програм фахівців мистецьких спеціальностей, адже спрямований на «забезпечення упровадження освіти, орієнтованої на компетенції», мета яких - допомогти у «складанні навчальних планів, формуванні методик навчання і системи діагностики якості освіти» [2, с. 83].

При цьому О. Ільченко та Я. Сверлюк виокремлюють методи навчальної діяльності: «методи організації навчально-пізнавальної діяльності, методи розвитку музичних здібностей, методи навчання музичній діяльності, методи вивчення музичного твору, методи освоєння знань 3 окремих навчальних дисциплін» [1, с. 42]. Інтерактивні методи навчання в галузі музичної педагогіки досліджують не лише науковці, а й учителі музичного мистецтва, зокрема О. Семенюк, О. Пашкевич, Л. Кондрацька. При цьому методику використання дидактичних ігор на уроках музики пропонують у своїх роботах О. Пермяков, I. Власенко та О. Лаврентьєва.

Незважаючи на значну кількість досліджень 3 означеної проблеми, питання впровадження в освітній процес інтерактивних методів навчання у ході підготовки магістрів спеціальності «Музичне мистецтво» і надалі залишається актуальним, а отже, потребує більш грунтовного аналізу, чому і присвячена наша стаття.

Мета статті - проаналізувати форми і методи інтерактивного навчання, а також методики проведення практичних занять із дисципліни «Інтерактивні технології навчання музичного мистецтва» освітньо-професійної програми підготовки фахівців спеціальності «Музичне мистецтво»; розглянути актуальні питання формування професійних компетенцій магістрів музичного мистецтва як майбутніх викладачів ЗВО.

Виклад основного матеріалу. Освітній ступінь магістра в галузі музики передбачає формування таких ключових компетенцій, як широка ерудиція, фундаментальність наукових та прикладних знань, володіння методологією наукових досліджень, здатність до професійного застосування сучасних інформаційних технологій на практиці, тобто «здатність до плідної практичної та мистецько-просвітницької діяльності у 3ВО» [3, с. 7]. У навчальні плани підготовки магістрів уведені дисципліни, що сприяють формуванню представлених професійних знань та навичок. Зокрема, метою дисципліни «Інтерактивні технології навчання музичного мистецтва» $€$ вивчення методики проведення практичних занять у різноманітних формах взаємодії. Використання в межах даного курсу дискусійних методів, тренінгів, рольових імітаційних ігор розглядаються у двох аспектах: вивчення навчального матеріалу й удосконалення професійних якостей магістра як майбутнього викладача.

Передбачається, що студенти, працюючи в умовах тісної взаємодії, активно та із зацікавленням вивчатимуть матеріал, що позитивно відобразиться на якості навчання. Ці методи поєднані із навчальною метою сприяють розвитку й удосконаленню особистості майбутнього фахівця, виховують у нього здатність до саморозвитку.

Навчальний процес 3 використанням інтерактивних технологій відбувається за умови постійної активної взаємодії всіх учасників навчального процесу. Використання рольових ігор передбачає моделювання життєвих і виробничих ситуацій, а дискусійні методи вимагають спільного вирішення проблем на основі аналізу питань, що вивчаються, та ефективно сприяють формуванню професійних навичок і вмінь, створенню атмосфери співробітництва та взаємодії. Під час інтерактивного навчання студенти вчаться критично мислити, приймати продумані й виважені рішення, а також дотримуватися у процесі спілкування правил толерантності [5].

Методика викладання фахових дисциплін для студентів спеціальності «Музичне мистецтво» передбачає також й індивідуальну форму занять (у нашому випадку - спецінструмент, вокал, диригування, ансамбль, хоровий та оркестровий класи тощо). Так, завдяки діалоговій взаємодії викладача і студентів як специфічної умови навчання мистецтва формуються необхідні для майбутнього фахівця компетенції, набувається мистецький досвід [4].

Навчальна дисципліна «Інтерактивні технології навчання музичного мистецтва» покликана не лише формувати в студентів знання сучасних методів викладання фахових дисциплін, а й уміння оперувати ними в майбутній професійній діяльності, зокрема здобувачі освіти ознайомлюються $з$ активною та інтерактивною моделями навчання, методикою застосування на заняттях із музичного мистецтва рольових та імітаційних ігор, дискусій, тренінгів.

Аби наочно продемонструвати це студентам-магістрантам, нами було розроблено низку практичних занять, приклади деяких із них пропонуємо для розгляду.

\section{Практичне заняття 1}

Тема: Активні та інтерактивні моделі навчання.

Mema: ознайомити студентів із активними й інтерактивними моделями навчання; окреслити форми і методи інтерактивного навчання.

Форма взаємодіï: інтерактивна вправа.

На попередньому лекційному занятті студентам було запропоновано поміркувати над такими питаннями: значення активних та інтерактивних моделей навчання; особливості впровадження ECTS 
у підготовку майбутнього музиканта; сучасні вимоги до розробки навчальних програм; модульно-рейтингове оцінювання; структура інтерактивного заняття; інтерактивні технології навчання.

На початку практичного заняття викладач звертає увагу студентів на те, що обов'язковою його складовою є їхнє вміння висловлювати власну думку, аргументувати, виокремлювати головне, пам'ятаючи при цьому про правила толерантності щодо опонентів.

Ураховуючи тематику заняття, студентам можна запропонувати подискутувати, наприклад, над такими питаннями:

- Сутність активних та інтерактивних моделей навчання.

- Чим мене може зацікавити інтерактивне заняття?

- Які форми інтерактивних занять можна застосовувати у викладанні фахових дисциплін?

- Які інтерактивні методи навчання можна застосувати у процесі викладання фахових дисциплін?

Основну частину заняття присвячуємо інтерактивній вправі, метою якої є вивчення навчального матеріалу, досягнення результатів заняття. Для цього об'єднаємо студентів у групи (зазвичай по 2 особи) та скористаємося методом «снігова куля».

Спочатку пропонуємо студентам обговорити вищеозначені питання у парах, згодом, поступово збільшуючи кількість учасників у групі, намагаємося досягнути того, щоб почути якомога більше думок і пропозицій (їх варто зафіксувати, наприклад, на великому листі паперу для подальшого представлення). На завершальному етапі дискусії студенти приходять до спільного рішення про значення інтерактивних моделей навчання, форм і методів навчальної діяльності, які варто застосовувати в ході вивчення дисципліни «Інтерактивні технології навчання музичного мистецтва».

Завершується заняття підбиттям підсумків та оцінюванням результатів роботи всіх учасників обговорення.

\section{Практичне заняття 2}

Тема: Методика проведення занять із фахових дисциплін.

Mema: перевірити вміння студентів застосовувати інтерактивні технології на практиці. ція.

Форма взаємодії: практичне заняття-конферен-

Перед початком практичного заняття викладач пропонує студентам «перевтілитися» в дослідників та поміркувати над вирішенням проблеми, як провести інтерактивне заняття з певної дисципліни (наприклад, «Методика викладання гри на музичних інструментах», «Методика викладання постановки голосу», «Методика викладання дисциплін аудіотехнологічного комплексу», «Методика викладання гри на фортепіано», «Методика вокальної самопідготовки», «Методика викладання диригування»). 3 цією метою студентів розподіляють на три групи: доповідачів, опонентів, учасників конференції. Викладач при цьому виконує роль спостерігача, помічника, координатора-споглядача тощо.

Головне завдання даної форми роботи - психологічно та практично підготувати студентів до участі в різноманітних конференціях, навчити не боятися аудиторії. етапи:

Практичне заняття-конференція передбачає такі

1) Оголошення теми доповіді.

2) Розподіл ролей.
3) Виступ «доповідача» із повідомленням (у ході виступу варто окреслити такі питання: назва дисципліни; тема; правильно обраний інтерактивний метод для конкретної дисципліни, що визначається її метою та особливостями викладання; структура заняття та його етапи; доцільність використання групової взаємодії; проблема для розв'язання та шляхи ії вирішення).

4) Обговорення доповіді «опонентами» спільно 3 «доповідачем» та «учасниками конференції».

5) Колективне оцінювання результатів обговорення.

Метою представленої вище взаємодії є трансформація теоретичних знань у практичний аспект, усвідомлення основних закономірностей професійної діяльності викладача. Завдяки такій формі роботи студенти набувають навичок проведення інтерактивного заняття, вчаться висловлювати свої думки на загал, дискутувати й опонувати [5].

У процесі вивчення конкретної дисципліни на основі запропонованої технології в студентів з'являється можливість для педагогічної імпровізації, наприклад, відповідно до певної теми обрати доречні в даній ситуації методи інтерактивної взаємодії.

Практичні заняття з представленої теми також можна провести у формі рольової гри, методів «портфоліо», «акваріум» та ін.

\section{Практичне заняття 3}

\section{Тема: Технологія тренінгу.}

Mema: ознайомити студентів із технологією тренінгу.

У ході вивчення даної теми можна використати такі інтерактивні методи навчання: «акваріум», «ажурна пилка», «мозковий штурм», «круглий стіл», кейс-метод та ін.

На нашу думку, найбільш вдалим для розкриття представленої теми є метод «ажурна пилка». 3 цією метою викладачеві заздалегідь необхідно підготувати роздатковий матеріал: картки різних кольорів (за кількістю студентських груп) із вказаними на них цифрами (від 1 до 5 - відповідно до кількості запитань), наприклад:

1) Тренінг партнерського спілкування (синя картка).

2) Тренінг сенситивності (жовта картка).

3) Тренінг креативності (червона картка).

Відповідно, кожен студент отримує певну картку.

На периому emani групи формуються за кольорами. Кожній групі викладач роздає поділений на частини інформаційний матеріал для опрацювання.

Час для роботи - 15-20 хв.

\section{Завдання:}

- охарактеризуйте основні завдання тренінгу сенситивності, наведіть приклади вправ;

- виокреміть основні завдання тренінгу партнерського спілкування, наведіть приклади вправ;

- означте головні завдання тренінгу креативності, наведіть приклади вправ;

- запропонуйте вправи, які будуть доречними в ході практичної діяльності.

На другому emani групи формуються за числами.

Завдання: почергово студенти мають розповісти, що нового вони дізналися, працюючи в попередній групі.

Час для роботи $-15-20$ хв.

Завдяки даній формі роботи всі без винятку студенти беруть участь у дискусії, опрацьовуючи матеріал теми.

Tpemiŭ eman - перевірка вивченого матеріалу (3 цією метою можна використати метод «мікрофон», тестування тощо). 
Таким чином, студенти виконали подвійне завдання: не лише ознайомилися з новою темою «Технологія тренінгу», а й, використовуючи метод «ажурна пилка», навчилися працювати в різних групах.

Із метою закріплення вивченого матеріалу на наступних практичних заняттях викладачем для студентів були запропоновані тренінги партнерського спілкування, які викликали в них неабиякий інтерес.

Отже, у процесі вивчення дисципліни «Інтерактивні технології навчання музичного мистецтва» студенти ознайомилися 3 інтерактивними технологіями навчання музичного мистецтва, окреслили особливості підготовки до занять, а також, що суттєво, визначили їх переваги та недоліки. Крім того, вони мали можливість закріпити отримані знання та навички на практиці, зокрема долучилися до підготовки презентацій 3 окремих тем професійних дисциплін, як-от: «Особливості виконавського стилю», «Історичні етапи розвитку музичного виконавства», «Джаз і сучасна музика», «Інструментознавство», «Методика викладання фахових дисциплін» та ін.

Висновки. Підсумовуючи викладене в статті, зауважимо, що використання студентами магістратури інтерактивних методів навчання у вивченні фахових дисциплін сприяє досконалому засвоєнню навчального матеріалу. При цьому практичні заняття, що базуються на інтерактивних методиках, формують комунікативні здібності майбутніх фахівців-музикантів, їх здатність до активної взаємодії з учасниками освітнього процесу, мотивують до застосування сучасних методів викладання дисциплін.
Подальші наші дослідження плануємо спрямувати на вивчення критеріїв модульно-рейтингового оцінювання знань студентів на заняттях за методикою інтерактивного навчання, що покликані стимулювати їх навчальну діяльність, викликати зацікавленість у вивченні дисциплін.

\section{СПИСОК ВИКОРИСТАНОЇ ЛІТЕРАТУРИ}

1. Ільченко О. О. Методологічні проблеми професійної музичної освіти : монографія / О. О. Ільченко, Я. В. Сверлюк. - Рівне : Перспектива, 2004. - 200 с.

2. Козлова Г. Компетентнісний підхід до навчання студентів і викладачів / Г. Козлова, Т. Кублікова // Вища школа. - 2011. - № 4 - С. 83-93.

3. Лісовий В. А. Магістерський рівень вищої освіти як основа професійного розвитку майбутніх фахівців музичного мистецтва / В. А. Лісовий // Мистецтво та освіта. - 2018. - № 1 (87). - С. 6-9.

4. Падалка Г. М. Педагогіка мистецтва: теорія і методика викладання фахових дисциплін : монографія / Г. М. Падалка. - К. : Освіта України, 2008. - 274 с.

5. П'ятакова Г. П. Інтерактивні методики та специфіка їх застосування у вищій школі : методичний посібник / Г. П. П'яткова, О. Л. Глотов. - Тернопіль : Studia metodologica, 2002. - $20 \mathrm{c}$.

6. П'яткова Г. П. Технологія інтерактивного навчання у вищій школі : навчально-методичний посібник / Г. П. П'яткова. - Львів : Видавничий центр ЛНУ імені І. Франка, 2008. - 120 с.

Дата надходження до редакиї: 10.12.2019 р.

Богдан СТОЛЯРЧУК, професор, завідувач кафедри музичного фольклору Iнституту мистеитв

Рівненського державного гуманітарного університету, заслужений діяч мистеитв Украӥни

\section{ІНСТРУМЕНТАЛЬНИЙ АНСАМБЛЬ ТРАДИЦІЙНОЇ НАРОДНОЇ МУЗИКИ «ХУТІРСЬКІ МУЗИКИ» ТА ЙОГО РОЛЬ У ВИХОВАННІ МАЙБУТНІХ КЕРІВНИКІВ ФОЛЬКЛОРНИХ КОЛЕКТИВІВ}

У статті представлено маловідомі сторінки щодо створення, становлення та розвитку інструментального ансамблю традииійної народної музики «Хутірські музики». Розкрито його роль у підготовиі майбутніх організаторів $і$ керівників ансамблів троїстих музик для закладів освіти і культури.

Ключові слова: ансамбль «Хутірські музики», фольклорист, басоля, ичимбали
В статье рассмотрень малоизвестные страницьь создания, становления и развития инструментального ансамбля традиционной народной музыки «Хуторские музыки». Раскрыта его роль в подготовке будущих организаторов и руководителей ансамблей тройственных музык для учреждений образования и культуры.

Ключевые слова: ансамбль «Хуторские музыки», фольклорист, басоль, ичимбальл. 